\title{
Lichen polysaccharides and their relation to reindeer/caribou nutrition
}

\author{
B. SVIHUS AND Ø. HOLAND
}

Authors are with the Department of Animal Science, Agricultural University of Norway, P.O. Box 5025, N-1432 Ås, Norway.

\begin{abstract}
Samples of Cetraria islandica, Cetraria nivalis, Cladina stellaris, Cladina arbuscula, Cladina rangiferina and Stereocaulon paschale were collected at 3 sites in 2 mountain areas in Norway. Alectoria ochroleuca was collected at 3 sites in 1 of the mountain areas. Lichens contained between 83 and $93 \%$ fiber, measured by the dietary fiber analysis, with Cladina spp. containing significantly more fiber than the other lichen species. The fiber consisted mainly of mannose, galactose, and glucose, but the relative content of each monosaccharide differed between species. Fibers from Cetraria spp. and Alectoria ochroleuca contained significantly more glucose than those from Cladina spp. and Stereocaulon paschale, while Cladina spp. and Stereocaulon paschale contained significantly more mannose and galactose. The higher glucose content in Cetraria spp. and Alectoria ochroleuca was reflected in a high lichenan content in these species, while the Cladina spp. and Stereocaulon paschale contained no lichenan. Solubility of the fiber fraction in hot water was strongly correlated to lichenan content, and great differences existed between species. Less than $5 \%$ of the dietary fiber was soluble in lichens of the Cladina genus, while more than $50 \%$ of the fiber was soluble in Cetraria islandica and Alectoria ochroleuca. Twenty-one percent of the dietary fiber was soluble in Cetraria nivalis. In vitro gas production experiments using rumen inocula from reindeer revealed a higher gas production rate the first 5 hours of incubation in Cetraria islandica, Cetraria nivalis, and in Alectoria ochroleuca compared to Cladina spp. and Stereocaulon paschale. Maximum production rate was observed at about 13 hours and dropped rapidly thereafter. No systematical differences in gas production rate between lichens species were observed after the initial phase. Differences in gas production rate in the initial phase resulted in higher total gas production in Cetraria islandica, Cetraria nivalis and in Alectoria ochroleuca compared to Cladina spp. and Stereocaulon paschale the first 9 hours of incubation. Total gas production after 52 hours of incubation did not vary between species. Gas production characteristics indicate that the amount of readily fermentable fraction was greater, whereas the amount slowly fermentable fraction was lower in lichens of the Cetraria genus and in Alectoria ochroleuca compared to Cladina spp. and Stereocaulon paschale. The water-soluble fraction is easy available for rumen micro-organisms and the results indicate a close relationship between high gas production in the initial phase and high proportion of water soluble fibers and/or lichenan content. Content, composition, and solubility of the fiber fraction could thus be potentially important factors determining nutritive value of the lichen for reindeer/caribou.
\end{abstract}

Key Words: Cetraria spp., Cladina spp., Alectoria ochroleuca, Stereocaulon paschale, dietary fiber, lichenan, in vitro gas production

Manuscript accepted 6 Mar. 2000.

\section{Resumen}

Se colectaron muestras de Cetaria islandica, Cetaria nivalis, Cladina stellaris, Cladina arbuscula, Caldina rangiferina y Stereocaulon paschale en 3 sitios de 2 áeas de montañosas de Noruega. Se colecto Alectoria ochroleuca en 3 sitios de una de las áeas montañosas. Los láquenes contenáan de 83 a $93 \%$ de fibra, medida por el an-lisis de fibra dietaria, las especies de Cladina tenáan significativamente mas de fibra que las otras especies de láquenes. La fibra consistió principalmente de manosa, galactosa y glucosa, pero el contenido relativo de cada monosacáidos difirió entre especies. La fibra de las especies de Cetaria y Alectoria ochroleuca contenáan significativamente mas glucosa que la fibra de las especies de Cladina y Stereocaulon paschale, mientras que la fibra de las especies de Cladina y Stereocaulon paschale tenia mas manosa y galactosa. El alto contenido de glucosa de las especies de Cetaria y Alectoria ochroleuca se reflejó en un mayor contenido de liquenan en estas especies, mientras que las especies de Cladina y Stereocaulon paschale no contenáan liquenan. La solubilidad en agua caliente de las fracciones de la fibra estuvo fuertemente correlacionada al contenido de liquenan y existen grandes diferencias entre especies En las especies de Cladina, menos del 5\% de la fibra dietaria fue soluble mientras que en las especies Cetaria islandica $y$ Alectoria ochroleuca mas del $50 \%$ de la fibra fue soluble y $21 \%$ de la fibra dietaria fue soluble en Cetaria nivalis. Experimentos de producción de gas in vitro utilizando inoculo ruminal de reno revelaron una alta tasa de producción de gas en la primeras 5 horas de incubación de Cetaria isalndica, Cetaria nivalis y Alectoria ochroleu ca comparado con las especies de Cladina y Stereocaulon paschale. La m·xima tasa de producción de gas se observó a las 13 horas y a partir de aquá disminuyó r-pidamente. Despues de la fase inicial no se observaron diferencias sistem·ticas entre especies de láquenes en la tasa de producción de gas. Las diferencias en la tasa de producción de gas en la fase inicial resultaron en una mayor producción de gas en las especies Cetaria islandica, Cetaria nivalis y Alectoria ochroleuca compardo con las especies de Cladina y Stereocaulon paschale, esto durante las primeras 9 horas de incubación. La producción total de gas después de 52 horas de incubación no varió entre especies. Las caracterásticas de producción de gas indican que la cantidad de la fracción de r·pida fermentación fue mayor en tanto que la cantidad de la fracción de lenta fermentación fue menor en los láquenes del genero Cetaria y en Alectoria ochroleuca comparado con las especies de Cladina y Stereocaulon paschale. La fracción soluble en agua es de alta disponibilidad para los microorganismos del rumen y los resultados indican una estrecha relación entre la alta producción de gas en la fase inicial y una alta proporción de fibras solubles en agua y/o contenido de liquenan. El contenido, composición y solubilidad de las fracciones de la fibra pudieran ser factores potencialmente importantes en determinar el valor nutritivo de los láquenes para los renos y carib`s. 
In winter, lichens are the principal fodder resource for reindeer/caribou throughout most of their range (Andreyev 1977, Eriksson et al. 1981, Russell and Martell 1984), especially mat-forming species of the genera Cetraria and Cladina when available (Andreyev 1977, Eriksson et al. 1981). In the taiga belt, the aboreal lichens Usnea spp. and Bryoria spp. may also play an important role in the winter diet (Andreyev 1977).

Due to high preference by reindeer, but slow potential growth rate (Andreyev 1977, Tveitnes 1980, Virtala 1992), lichens are vulnerable to overgrazing. Overgrazing reduces lichens density, but may also change the relative abundance of different lichen species, since their vulnerability to grazing and trampling varies (Klein 1987). Also their ability to recoup from over-utilisation varies (Andreyev 1977, Gaare \& Skogland 1980, Klein 1987). Sound management of lichens is therefore essential in both wild reindeer and caribou management and in semidomestic reindeer husbandry.

Lichens are considered to mainly consist of different carbohydrate fractions. However, little has been done to quantify the carbohydrate content in lichens of importance in reindeer nutrition. In addition, solubility of the fiber fraction may be a useful parameter, since it could influence the initial lag phase of rumen fermentation and hence influence lichen digestibility.

Early investigations have revealed that reindeer have a greater ability to digest lichens compared to, for example, sheep (Presthegge 1954). The higher capacity of reindeer and caribou to exploit lichens than other northern ungulates is a key factor in understanding their success throughout most of the circumpolar region. A more detailed knowledge of the composition of the most important lichens species is a prerequisite to determine factors involved in digestion of lichens in reindeer/caribou. This may have bearings for management of lichen ranges and in evaluation of quality and stocking capacity of these.

The objectives of this study were to quantify the carbohydrate composition and solubility of lichens, and to study the ruminal breakdown pattern of these lichens for reindeer.

\section{Material and methods}

Lichens of the species Cetraria islandi ca (L.), Cetraria nivalis (L.), Cladina stel laris (Opiz), Cladina arbuscula (Waller), Cladina rangiferina (L.) and Stereocaulon paschale (L.) were collected from 3 randomly selected sites of alpine ridge vegetation in 2 mountain areas in central Norway; Jotunheimen $\left(61^{\circ} 10^{\prime}\right)$ and Hardangervidda $\left(60^{\circ} 30^{\prime}\right)$ in August 1996. In addition, Alectoria ochroleuca was collected from 3 sites in Hardangervidda. The samples were picked by hand by gently breaking off 1 to $3 \mathrm{~cm}$ of the upper dry part of the podetium. The reindeer grazing impact of the lichen mat was low to moderate at all sites.

The samples were air-dried and cleaned by hand for foreign substances. To meet the requirements for dietary fiber analysis, the samples were ground on a laboratory rotor mill fitted with a $0.5 \mathrm{~mm}$ screen. Dry matter (DM) was determined after drying at $105^{\circ} \mathrm{C}$ overnight, ash was determined after 4 hours at $550^{\circ} \mathrm{C}$, and crude protein was determined as Kjeldahl N X 6.25. Crude fiber was analyzed according to the Weende method (Henneberg and Stohmann 1859), with the modification that $200 \mathrm{mg}$ instead of $1 \mathrm{~g}$ was used to avoid viscosity problems during filtration. Acid detergent fiber (ADF) and neutral detergent fiber (NDF) was analysed according to Van Soest and Wine (1967), with the amount of sample reduced to $150 \mathrm{mg}$. Starch content corrected for free glucose content was determined according to the method of McCleary et al. (1994). Total mixed-linked (1-3)(1-4)-ß-D-glucan (lichenan) content was determined according to AOAC method 995.16 (McCleary and Codd 1991). Lichenans were degraded to glucose by using lichenase and $\beta$-glucosidase, and glucose was determined by spectrophotometry. However, initial experimentation showed that due to the high amounts of lichenan in some lichens, the amount of sample needed to be reduced to $25 \mathrm{mg}$. The boiling time with sodium phosphate buffer was also increased to 13 minutes to assure solubilisation of the sample. Total, soluble and insoluble dietary fiber were analyzed according to the enzymatic-gravimetric AOAC method 991.43 (Lee et al. 1992), but due to high fiber content and the problems of high viscosity during filtration, the amount of sample was reduced to $300 \mathrm{mg}$. The samples from Harangervidda were also analysed for monosaccharide composition of the fiber fraction. This analysis was conducted at the Norwegian Food Research Institute by gas-liquid chromatography according to the method of Englyst et al. (1992), with the modification that the enzymatic pre-treatment to digest starch was not performed.
For determination of the ruminal breakdown pattern, a $200 \mathrm{mg}$ sample was weighed into $100 \mathrm{ml}$ syringes in duplicate. Ruminal fluids ( $200 \mathrm{ml}$ ) from 3 rumen fistulated reindeer calves fed a lichen dominated diet were pooled, mixed, and strained through 4 layers of cheesecloth and added to preheated buffer (Menke and Steingass 1988) in a 1:3 ratio. This was done for each of the 3 runs performed during a 3 week period. Thirty $\mathrm{ml}$ of the ruminal fluid buffer solution was added to each syringe and kept at $38^{\circ} \mathrm{C}$ in an incubator. In vitro gas production of each lichen species, in addition to cellulose standard (Whatman No.1 filter paper) was measured according to the method described by Menke and Steingass (1988). Gas production was recorded after 1, 2, 3, $5,7,9,13,18,24,28,32,34,38,46$, and 52 hours. Gas production was corrected for blank gas production; triplicates of buffered rumen without sample in each run. The syringes were shaken by hand twice in the first hour and then 4 times daily during the rest of the incubation. Lichens species from 1 site of Hardangervidda and 1 of Jotunheimen were used in the experiment. Ten days before start and throughout the experimental period the animals were offered $1,000 \mathrm{~g}$ DM per day of a diet consisting of $50 \%$ Cladina stellaris and $50 \%$ Cetraria islandica. The kinetics of fermentation were fitted to the exponential equation; $\mathrm{p}=\mathrm{a}+\mathrm{b}\left(1-\mathrm{e}^{\mathrm{ct}}\right)$ according to Ørskov and McDonald (1979) and Blümmel and Ørskov (1993), where p represents gas production at time $\mathrm{t},(\mathrm{a}+\mathrm{b})$ the potential gas production, $\mathrm{c}$ the rate of production. The a value is the intercept of the curve whereas the $b$ value represents the fermentation of insoluble but potentially fermentable fractions of the feed.

Statistical analysis was performed using the Statistical Analysis System (SAS 1987). In the analysis of variance, a factorial design with location (mountain area) and lichen species as factors were used for the lichens collected in both mountain areas and for the parameters analysed from both locations. For pair-wise comparisons, the Ryan-Einot-Gabriel-Welsh multiple F-test was used. For the in vitro gas production data, a factorial analysis of variance design with run and lichen species as factors were performed, followed by Duncan's Multiple range test (SAS 1987) when appropriate. 
Table 1. Content of dry matter, ash, crude protein, starch, and fiber fractions in lichens ${ }^{1}$.

\begin{tabular}{|c|c|c|c|c|c|c|c|c|}
\hline & $\begin{array}{c}\text { No. of } \\
\text { obs }\end{array}$ & $\begin{array}{c}\text { Dry } \\
\text { matter }\end{array}$ & Ash & $\begin{array}{l}\text { Crude } \\
\text { protein }\end{array}$ & Starch & $\begin{array}{l}\text { Crude } \\
\text { fiber }\end{array}$ & $\mathrm{ADF}$ & $\mathrm{NDF}$ \\
\hline & & & & & $-(\%$ of $D$ & - - - - & & \\
\hline Cetraria nivalis & 6 & 91.2 & $1.3^{\mathrm{a}} \pm 0.25$ & $2.0^{c} \pm 0.19$ & $0.2^{\mathrm{c}} \pm 0.09$ & $1.0^{c} \pm 0.19$ & $1.6^{\mathrm{bc}} \pm 1.22$ & $6.8^{c} \pm 4.03$ \\
\hline Cladina stellaris & 6 & 91.7 & $0.6^{\mathrm{bc}} \pm 0.26$ & $1.9^{\mathrm{c}} \pm 0.08$ & $0.2^{\mathrm{bc}} \pm 0.02$ & $11.8^{\mathrm{b}} \pm 2.90$ & $1.6^{\mathrm{bc}} \pm 0.60$ & $67.6^{a} \pm 9.02$ \\
\hline Cladina arbuscula & 6 & 91.5 & $0.4^{\mathrm{cd}} \pm 0.01$ & $2.7^{b} \pm 0.17$ & $0.2^{\mathrm{bc}} \pm 0.02$ & $9.9^{\mathrm{b}} \pm 4.42$ & $1.8^{\mathrm{bc}} \pm 0.71$ & $72.7^{\mathrm{a}} \pm 4.76$ \\
\hline Cladina rangiferina & 6 & 92.3 & $0.3^{\mathrm{d}} \pm 0.05$ & $2.5^{\mathrm{b}} \pm 0.07$ & $0.3^{\mathrm{bc}} \pm 0.06$ & $24.2^{\mathrm{a}} \pm 3.43$ & $2.9^{\mathrm{ab}} \pm 1.75$ & $70.3^{\mathrm{a}} \pm 3.27$ \\
\hline
\end{tabular}

${ }^{\mathrm{abcd}}$ Means within column without common superscripts are significantly $(\mathrm{P}<0.05)$ different.

${ }^{1}$ Values are means \pm standard deviation.

\section{Results}

Lichens from the mountain area Jotunheimen contained in average 2.3, 1.3, 9.4, and $1.3 \%$ more of crude fiber, ADF, NDF and total dietary fiber, respectively, than lichens from Hardangervidda. However, a significant effect of location was only found for $\mathrm{ADF} \mathrm{P}(\mathrm{P}<0.05)$. The large difference between mountain areas in NDF content was in particular caused by Cetraria spp., where the NDF content in average was more than twice as high at Jotunheimen as at Hardangervidda.

All the samples contained more than 90\% DM after air drying, but some variation existed between species (Table 1). Ash content varied significantly between species, with the ash content of Cetraria nivalis being more than twice the amount $(\mathrm{P}<0.05)$ than for the other species (Table 1). Significant differences also occurred between the other species. Stereocaulon paschale had 3 times higher $(\mathrm{P}<0.05)$ crude protein content than the other lichen species, while the crude protein content in Cetraria nivalis and Cladina stellaris was lower $(\mathrm{P}<0.05)$ than for the other species. Starch content was below $0.5 \%$ in all samples except for samples from Cetraria islandica, which had an average starch content of $0.55 \%$.

Crude fiber content in different lichen species varied between 1 and $24.2 \%$, the content being higher $(\mathrm{P}<0.05)$ in Cladina spp. and Stereocaulon paschale than in Cetraria and Alectoria ochroleuca (Table 1). In addition, Cladina rangiferina had a higher $(\mathrm{P}<0.05)$ crude fiber content than any of the other lichen species. Only small differences in ADF content were observed between species, while NDF content varied greatly (Table 1). The NDF content was significantly higher in lichens of the Cladina genus than in the other lichen species, and Stereocaulon paschale had a significantly higher NDF content than Cetraria spp. and Alectoria ochroleuca.

The total dietary fiber percentage was

higher than 77 in all samples analysed, and relatively little variation was found within species (Table 2). However, dietary fiber content was higher $(\mathrm{P}<0.05)$ in lichens of the Cladina genus than in Cetraria islandica, Stereocaulon paschale, and Alectoria ochroleuca, while the value for Cetraria nivalis was intermediate.

Table 2. Total dietary fiber content of lichens.

\begin{tabular}{lccccc}
\hline \hline & No. of obs & Minimum & Maximum & Mean & Std. Dev. \\
\hline Cetraria nivalis & 6 & $-1-1 .-10$ & 93.7 & $88.68^{\mathrm{b}}$ & 3.278 \\
Cetraria islandica & 6 & 77.50 & 87.4 & $83.02^{\mathrm{c}}$ & 3.395 \\
Cladina stellaris & 6 & 88.00 & 93.60 & $91.12^{\mathrm{ab}}$ & 1.940 \\
Cladina arbuscula & 6 & 89.50 & 95.00 & $92.23^{\mathrm{ab}}$ & 1.793 \\
Cladina rangiferina & 6 & 90.50 & 95.00 & $93.10^{\mathrm{a}}$ & 1.614 \\
Stereocaulon paschale & 6 & 82.30 & 88.00 & $84.80^{\mathrm{c}}$ & 2.045 \\
Alectoria ochroleuca & 3 & 84.00 & 85.80 & $84.80^{\mathrm{c}}$ & 0.917 \\
\hline
\end{tabular}

${ }^{\mathrm{abc}}$ Means within column without common superscripts are significantly $(\mathrm{P}<0.05)$ different.

The solubility of the dietary fiber, measured as the amount of dietary fiber soluble in water at $60^{\circ} \mathrm{C}$, varied greatly between species and genera (Table 3 ). While less than $5 \%$ of the dietary fiber was soluble in lichens of the Cladina genus, more than $50 \%$ of the fiber was soluble in Cetraria islandica and Alectoria ochroleuca. In Cetraria nivalis, $21 \%$ of the dietary fiber was soluble. The soluble dietary fiber content was only slightly higher in Stereocaulon paschale than in lichens of the Cladina genus.

The analysis of lichenan content revealed that this fiber fraction was only present in Cetraria spp. and Alectoria ochroleuca (Table 4). The content was higher $(\mathrm{P}<0.05)$ in Alectoria ochroleuca than in Cetraria spp., and higher $(\mathrm{P}<$ $0.05)$ in Cetraria islandica than in Cetraria nivalis. Lichenan content varied little within species.

Table 3. Soluble dietary fiber content of lichens.

\begin{tabular}{|c|c|c|c|c|c|}
\hline & No. of obs & Minimum & Maximum & Mean & Std. Dev. \\
\hline & & \multicolumn{4}{|c|}{ 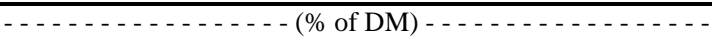 } \\
\hline Cetraria nivalis & 6 & 14.00 & 23.90 & $18.70 \mathrm{c}$ & 3.927 \\
\hline Cetraria islandica & 6 & 44.70 & 54.30 & $49.83 \mathrm{a}$ & 3.721 \\
\hline Cladina stellaris & 6 & 0.00 & 1.90 & $1.10 \mathrm{e}$ & 0.876 \\
\hline Cladina arbuscula & 6 & 0.60 & 3.80 & $2.87 \mathrm{de}$ & 1.219 \\
\hline Cladina rangiferina & 6 & 0.00 & 4.10 & $1.87 \mathrm{de}$ & 1.546 \\
\hline Stereocaulon paschale & 6 & 2.60 & 7.00 & $5.55 \mathrm{~d}$ & 1.707 \\
\hline Alectoria ochroleuca & 3 & 42.40 & 47.10 & $44.33 b$ & 2.458 \\
\hline
\end{tabular}

${ }^{\mathrm{abcd}}$ Means within column without common superscripts are significantly $(\mathrm{P}<0.05)$ different

The analysis of fiber content by hydrolysis and determination of monosaccharide composition confirmed the observation from the dietary fiber analysis that lichens mainly consist of fiber (Table 5). However, fiber content was on average between 30 and $15 \%$ lower than that found in the dietary fiber analysis, depending on species considered. The content in Cetraria nivalis was lower $(\mathrm{P}<0.05)$ than in any other species, and the content in Stereocaulon paschale was lower $(\mathrm{P}<$ $0.05)$ than in the other species except Alectoria ochroleuca.

The monosaccharide composition of the 
Table 4. Total mixed-linked (1-3)(1-4)(-D-glucan (lichenan) content of lichens.

\begin{tabular}{|c|c|c|c|c|c|}
\hline & No. of obs & Minimum & Maximum & Mean & Std. Dev. \\
\hline & & \multicolumn{4}{|c|}{$(1$ of $\mathrm{D})(1)$} \\
\hline Cetraria nivalis & 6 & 16.48 & 18.14 & $17.31^{\mathrm{c}}$ & 0.606 \\
\hline Cetraria islandica & 6 & 24.47 & 27.12 & $25.99^{\mathrm{b}}$ & 1.007 \\
\hline Cladina stellaris & 6 & 0.03 & 0.10 & $0.07^{\mathrm{d}}$ & 0.022 \\
\hline Cladina arbuscula & 6 & 0.03 & 0.30 & $0.12^{\mathrm{d}}$ & 0.097 \\
\hline Cladina rangiferina & 6 & 0.03 & 0.17 & $0.08^{\mathrm{d}}$ & 0.049 \\
\hline Stereocaulon paschale & 6 & 0.02 & 0.07 & $0.05^{\mathrm{d}}$ & 0.018 \\
\hline Alectoria ochroleuca & 3 & 32.81 & 35.05 & $33.78^{\mathrm{a}}$ & 1.156 \\
\hline
\end{tabular}

Table 5. Monosaccharide content from the lichen fiber fraction $(n=3)$.

\begin{tabular}{|c|c|c|c|c|c|c|c|}
\hline & $\begin{array}{l}\text { Cetraria } \\
\text { nivalis }\end{array}$ & $\begin{array}{l}\text { Cetraria } \\
\text { islandica }\end{array}$ & $\begin{array}{l}\text { Cladina } \\
\text { stellaris }\end{array}$ & $\begin{array}{c}\text { Cladina } \\
\text { arbuscula }\end{array}$ & $\begin{array}{c}\text { Cladina } \\
\text { rangiferina }\end{array}$ & $\begin{array}{c}\text { Stereocaulon } \\
\text { paschale }\end{array}$ & $\begin{array}{c}\text { Alectoria } \\
\text { ochroleuca }\end{array}$ \\
\hline & \multicolumn{7}{|c|}{ 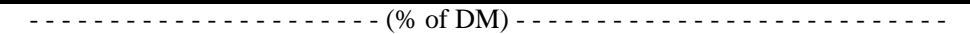 } \\
\hline Rhamnose & $0.3^{\mathrm{e}}$ & $0.6^{\mathrm{b}}$ & $0.5^{\mathrm{c}}$ & $0.4^{\mathrm{cd}}$ & $0.4^{\mathrm{c}}$ & $0.8^{\mathrm{a}}$ & $0.3^{\mathrm{de}}$ \\
\hline Fucose & $0.1^{\mathrm{a}}$ & $0.1^{\mathrm{a}}$ & $0.1^{\mathrm{a}}$ & $0.1^{\mathrm{a}}$ & $0.1^{\mathrm{a}}$ & $0.1^{\mathrm{a}}$ & $0.1^{\mathrm{a}}$ \\
\hline Arabinose & $0.6^{\mathrm{c}}$ & $1.0^{\mathrm{b}}$ & $0.7^{\mathrm{bc}}$ & $0.8^{\mathrm{bc}}$ & $0.8^{\mathrm{bc}}$ & $1.6^{\mathrm{a}}$ & $0.8^{\mathrm{bc}}$ \\
\hline Xylose & $0.2^{\mathrm{a}}$ & $0.5^{\mathrm{a}}$ & $0.4^{\mathrm{a}}$ & $0.4^{\mathrm{a}}$ & $0.4^{\mathrm{a}}$ & $0.5^{\mathrm{a}}$ & $0.2^{\mathrm{a}}$ \\
\hline Mannose & $13.9^{\mathrm{d}}$ & $11.9^{\mathrm{d}}$ & $42.9^{\mathrm{a}}$ & $35.9^{\mathrm{b}}$ & $33.2^{\mathrm{b}}$ & $26.6^{\mathrm{c}}$ & $6.7^{\mathrm{e}}$ \\
\hline Galactose & $14.7^{\mathrm{c}}$ & $10.4^{\mathrm{d}}$ & $18.2^{\mathrm{b}}$ & $26.7^{\mathrm{a}}$ & $17.6^{\mathrm{b}}$ & $17.6^{\mathrm{b}}$ & $5.9^{\mathrm{e}}$ \\
\hline Glucose & $32.3 c$ & $53.8 \mathrm{~b}$ & $22.3^{\mathrm{d}}$ & $19.3^{\mathrm{d}}$ & $33.9^{c}$ & $21.4^{\mathrm{d}}$ & $61.3^{\mathrm{a}}$ \\
\hline Uronic acid & $2.7^{\mathrm{a}}$ & $0.3^{\mathrm{c}}$ & $0.0^{\mathrm{d}}$ & $0.1^{\mathrm{d}}$ & $0.1^{\mathrm{d}}$ & $0.1^{\mathrm{d}}$ & $0.7^{\mathrm{b}}$ \\
\hline Total content ${ }^{1}$ & $58.4^{\mathrm{d}}$ & $70.8^{\mathrm{ab}}$ & $76.6^{\mathrm{a}}$ & $75.3^{\mathrm{ab}}$ & $77.9^{\mathrm{a}}$ & $61.7^{\mathrm{cd}}$ & $68.4^{\mathrm{bc}}$ \\
\hline
\end{tabular}

${ }^{a b c d}$ Means within a row without common superscripts are significantly $(\mathrm{P}<0.05)$ different.

${ }^{1}$ Calculated as anhydromonosaccharides to reflect the content as polysaccharides.

Table 6. Degradation characteristics (means \pm standard deviation) calculated from in vitro gas production runs $(n=3)$ of seven lichens species ${ }^{1}$.

\begin{tabular}{lclll}
\hline \hline Species & $\mathrm{a}$ & \multicolumn{1}{c}{$\mathrm{B}$} & \multicolumn{1}{c}{$\mathrm{c}$} & $(\mathrm{a}+\mathrm{b})$ \\
\hline Alectoria ochroleuca & $-5.9 \pm 0.8 \mathrm{a}$ & $76.9 \pm 3.0 \mathrm{c}$ & $0.056 \pm 0.0009 \mathrm{a}$ & $71.0 \pm 2.3 \mathrm{c}$ \\
Cetraria islandica & $-5.6 \pm 0.9 \mathrm{a}$ & $80.2 \pm 3.5 \mathrm{bc}$ & $0.051 \pm 0.0014 \mathrm{ab}$ & $74.6 \pm 2.5 \mathrm{ab}$ \\
Cetraria nivalis & $-5.6 \pm 1.3 \mathrm{a}$ & $77.2 \pm 3.0 \mathrm{c}$ & $0.054 \pm 0.0052 \mathrm{~b}$ & $71.6 \pm 3.1 \mathrm{bc}$ \\
Cladina arbuscula & $-8.2 \pm 0.5 \mathrm{~b}$ & $85.4 \pm 3.8 \mathrm{a}$ & $0.042 \pm 0.0041 \mathrm{c}$ & $77.3 \pm 3.6 \mathrm{a}$ \\
Cladina rangiferina & $-7.5 \pm 1.1 \mathrm{~b}$ & $84.5 \pm 2.3 \mathrm{a}$ & $0.042 \pm 0.0031 \mathrm{c}$ & $77.0 \pm 1.6 \mathrm{a}$ \\
Cladina stellaris & $-8.3 \pm 0.9 \mathrm{~b}$ & $83.7 \pm 1.9 \mathrm{ab}$ & $0.045 \pm 0.0031 \mathrm{c}$ & $75.4 \pm 1.7 \mathrm{a}$ \\
Stereocaulon paschale & $-7.7 \pm 1.3 \mathrm{~b}$ & $83.7 \pm 3.2 \mathrm{ab}$ & $0.044 \pm 0.0049 \mathrm{c}$ & $76.1 \pm 3.5 \mathrm{a}$ \\
\hline
\end{tabular}

${ }^{\mathrm{accd}}$ Means within column without common superscripts are significantly $\pm p<0.05$ ) different

${ }^{1}$ The kinetics of fermentation were fitted to the exponential equation; $\mathrm{p}=\mathrm{a}+\mathrm{b}\left(1^{\mathrm{e}-\mathrm{ct}}\right)$, where $\mathrm{p}$ represents gas production at time $t,(a+b)$ the potential gas production, $c$ the rate of production. The a value is the intercept of the curve whereas the $b$ value represents the fermentation of insoluble but potentially fermentable fractions of the feed.

fiber fraction differed between species, particularly for mannose, galactose and glucose (Table 5). Cladina spp. contained significantly more mannose and galactose than Cetraria spp. and Alectoria ochroleu ca, and Cladina stellaris and Cladina arbuscula contained significantly less glucose. Alectoria ochroleuca had the highest glucose content. Ninety percent of the fiber consisted of glucose in this species.

Some variation in gas production rate did occur between runs and between species at some incubation times, but no fixed ranking of runs and species were found. Pooled data shows that gas production rate was higher $(\mathrm{P}<0.05)$ during the first 5 hours of incubation in Cetraria nivalis, Cetraria islandica and Alectoria ochroleuca than in the other species (Fig. $1)$. The rate peaked in all species at 13 hours and dropped rapidly thereafter (Fig. lichens species whereas the mean slowly fermentable fraction was higher $(\mathrm{P}<0.05)$ in Cladina spp. and Stereocaulon paschale compared to Cetraria nivalis and Alectoria ochroleuca (Table 6). The rate of gas production (c) did not vary between runs or areas. The mean rate was higher $(\mathrm{P}$ $<0.05)$ in Cetraria islandica, Cetraria nivalis, and Alectoria ochroleuca than in the other lichens species (Table 6). Estimated potential gas production $(a+b)$ did vary between species with highest values in Cladina spp. and Stereocaulon paschale compared to Alectoria ochroleu ca and Cetraria nivalis (Table 6). No effect of run or area was found.

\section{Discussion}

The results of this study demonstrate that lichens mainly consist of different fiber fractions, and that large differences in fiber composition and solubility occurs between species and genera of lichen. These results also demonstrate the strong limitations of traditional fiber fractionation methods like crude fiber, NDF and ADF in determining fiber content of lichens, since only a small and variable fraction of the fiber was detected with these methods. The low crude fiber and ADF content is due to the strong detergents used, which solubilizes a large part of the fiber. These fiber fractions are also meant to reflect the content of strongly bound fibers. The NDF fraction, on the other hand, is meant to reflect a higher portion of the fibers. However, this method does not take into account the fraction of the fibers that is soluble in a neutral detergent. Thus, NDF strongly underestimates the fiber content of plant material with a high amount soluble fiber. To determine the total amount of carbohydrates that are not immediately available to the animal, more sophisticated methods like the dietary fiber analysis and the monosaccharide fractionation method are necessary. With these methods, soluble fibers are precipitated by addition of ethanol, and thus will not be lost in the supernatant. Although the fiber contents using monosaccharide fractionation on an average was between 30 and 15\% lower than when the dietary fiber analysis was used, the monosaccharide fractionation still confirms that the dietary fiber analysis reflects fiber content better than other methods. The suitability of dietary fiber as a measurement of fiber content is also reflected in the low standard deviation for this analysis within species. The lower 


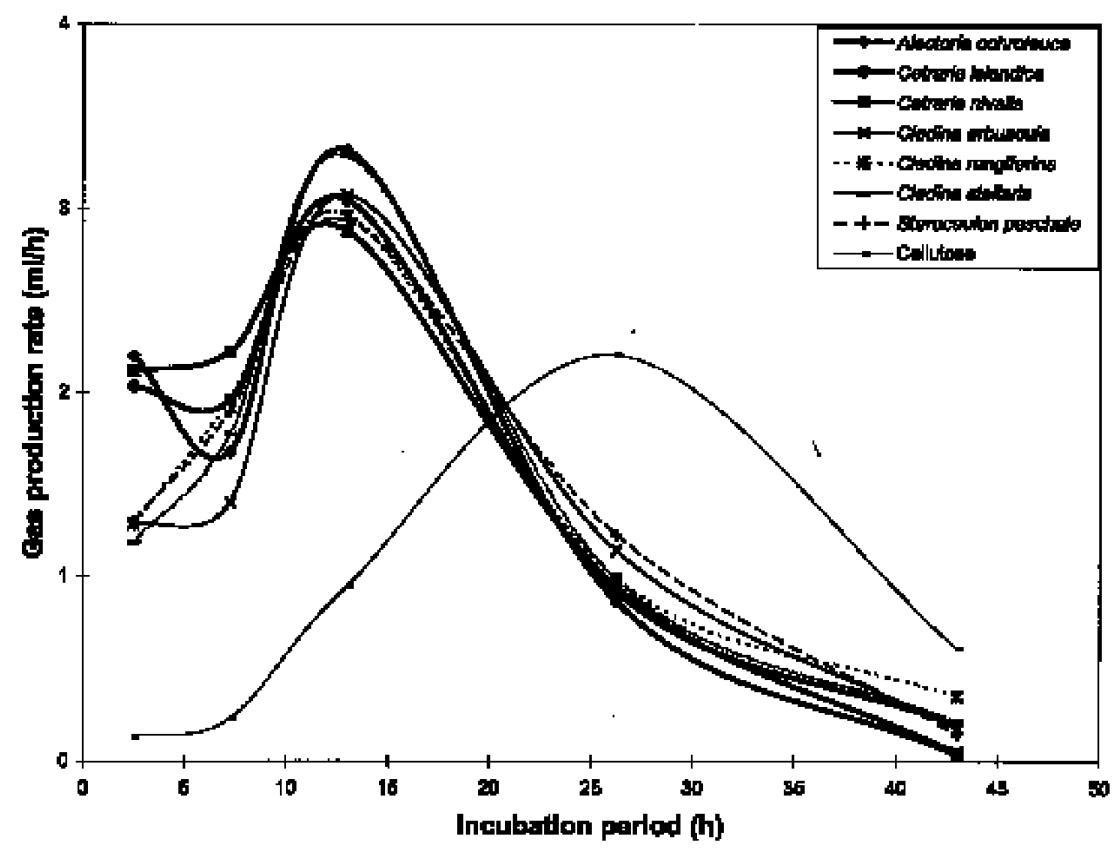

Fig. 1. Mean gas production rate of lichen species and cellulose at the following intervals: 0-5 hours, 5-9 hours, 9-18 hours, 18-34 hours and 34-52 hours through the incubation period.

value with the monosaccharide fractionation method could be due to losses that are known to occur during acid hydrolysis (Fincher and Stone 1986). The content of ash and crude protein and the content of 1.5 to $8.8 \%$ ether soluble substances as reported earlier (Garmo 1986, Presthegge 1954), also supports the values from the dietary fiber analysis, as these components constitute less than $12 \%$ of the lichen.

Garmo (1986) and Presthegge (1954), analysing the same lichen species, found at least twice as much ash as that found in our study. However, ash content varies with the extent of soil contamination in the samples. Protein content was comparable in these 3 studies. Garmo (1986) and Presthegge (1954) also reported much higher values (up to 4 times) for crude fiber than those obtained in this study. Solberg (1967), analysing 45 lichen species collected in Norway, also obtained much higher crude fiber values than those obtained in this study. The very fine grinding in our study (through $0.5 \mathrm{~mm}$ sieves) could be the cause of low crude fiber values, as the digested samples are filtered in the crude fiber analysis. However, the crude fiber content in these earlier studies were also much higher (4 to 6 times) in Cladina spp. than in Cetraria spp. and Alectoria ochroleuca, with Stereocaulon giving intermediate values.

Low values for ADF have also been reported before (Person et al. 1979, Danell et al. 1994). Person et al. (1979) reported ADF values of 4.6 and $3.7 \%$ in Cladina stellaris and Cetraria cucullata, respectively. In the same study, the NDF content was found to be 83.0 and $31.6 \%$ for the same species. Thus, in the study of Person et al. (1979) the values from the Van Soest analysis were higher than in our study. Danell et al. (1994) also reported higher NDF values in Cladina spp. (76-78\%) and Stereocaulon paschale (69\%) than in our study. This may also be caused by a fine grinding in our study. However, Cladina spp. contained much more NDF than Cetraria spp. both in our and Person et al. (1979) studies. Very low values for starch confirm a general view that lichens do not contain starch.

The dietary fiber analysis indicates that the fiber content is greater in lichens of the genus Cladina than in the other genera investigated in this study. In addition to the variation caused by variation in fat, ash, and protein content as presented above, variations in fiber content between species could be explained by variable content of mono- and oligosaccharides and other lowmolecular weight substances, like for example the lichen acids (Elix et al. 1984).

In all lichen species investigated in this study, mannose, galactose, and glucose were the major sugars present in polysaccharides. Hence, between 94 and $98 \%$ of the polysaccharides consisted of these hexoses. Solberg (1970) also concluded that lichen polysaccharides consisted of these monosaccharides. As our study demonstrated, glucose content may be present as lichenan. However, glucose may also be present as isolichenan, which is an $\alpha$-glucose present as polysaccharide through 1-3 and 1-4 bonds (Krämer et al. 1995). Another group of important polysaccharide in lichens is galactomannans. These polysaccharides generally consist of a backbone of mannose with galactose attached as side groups (Iacomini et al. 1985, Ingolfsdottir et al. 1994). The content of mannose in relation to galactose in our study supports the conclusion that galactomannans are major polysaccharides, particularly in lichens of the genera Cladina.

The fermentability of different lichen species in the initial phase using rumen fluid (the first 10 hours) seems to be related to solubility values in the fiber analysis, as lichens with a high solubility of the fibers also had a high initial fermentation rate. Differences in solubility of the fibers could thus affect nutritive value of different lichens for reindeer. In this respect, lichens of the Cladina genus might be particularly challenging to digest, since these lichens contain very low levels of fibers that are soluble in water at $60^{\circ} \mathrm{C}$.

The solubility and fermentability values obtained here also correspond to digestibility values obtained earlier. In a study by Garmo (1986), where rumen inoculum from sheep was used, the digestibility of dry matter was on an average $24 \%$ for Cladina spp. and 46 for Cetraria spp., while the values for Alectoria ochroleuca and Stereocaulon spp. were intermediate. Person et al. (1979), using rumen inoculum from reindeer and caribou, found similar values. Danell et al. (1994) reported in vitro organic matter digestibility (IVOMD) of Cladina stellaris, Cladina arbuscula, and Cladina rangiferina of 41,57 , and $69 \%$, respectively. In vivo digestibility of organic matter in Stereocaulon paschale has been found to be 48.5 (Jacobsen 1981), while Danell et al. (1994) reported an IVOMD of $36 \%$ for the same species. Presthegge (1954) compared digestibility of Cladina spp. and Cetraria spp. in experiments with sheep. In this study, organic matter digestibility was on an average $48 \%$ for Cladina spp. and 74 for Cetraria nivalis. However, digestibility was only $48 \%$ for Cetraria islandica. The digestibility of Cladina spp. has been found to be greater in reindeer than in sheep. Jacobsen and Skjenneberg (1976) for example, found the digestibility of organic matter in reindeer to be $75 \%$. No digestibility values for reindeer have to our knowledge been reported for the other lichen species.

Rumen turnover time is a critical para- 
meter in order to evaluate the biological significance of this finding. White et al. (1987) reported a rumen turnover time of reindeer fed lichens of about 30 hours. This is surprisingly long compared to the rapid rumen breakdown of lichens, and may reflect the low food intake during winter in reindeer (White et al. 1987). The low intake in winter is probably a strategy ensuring acceptable energy intake and minimising protein losses since energy intake on a lichen based diet is positively correlated to nitrogen losses (McEwan and Whitehead 1970). The long turnover time and the fact that no differences in total gas production occurred between lichens at around 30 hours in our study may indicate that variation in solubility plays a minor role for the nutritive value of lichen species in winter.

During summer most of the energy extracted from green vegetation by the females are transferred to their offspring as milk (White and Luick 1984). In fall, milk production drops and the females may build up their fat reserves. Fattening implies high energy intake, and the only carbohydrate rich fodder with high digestibility available in late fall is lichens. Still some of the winter green vegetation is available with a protein content ensuring a positive protein balance. Because of the high intake, rumen turnover time will be rather short. Thus, during fattening in fall, a highly soluble fiber fraction that is rapidly fermented, may contribute to higher energy intake, since digestibility can be regarded as a product of 2 competing processes; digestion and passage rate (Van Soest 1994).

This may indicate a selective pressure towards preference of lichens high in soluble fiber, especially in late fall when intake is high and turnover time is short. In initial preference studies conducted in November and December offering 5 species of lichens, Holleman and Luick (1977) reported a consistent preference for Cladina stellaris and Cladina rangiferina compared to Cetraria richardsonii. However, before the trials the animals were fed a Cladina spp. dominated diet which may influence diet preference. Nordberg et al. (1995) found that reindeer preferred Cladina spp. compared to Cetraria spp. in cafeteria trials conducted in October. The possible nutritional advantage of highly water-soluble lichens is not manifested in these trials and it is known that reindeer/caribou selectively graze lichens of the genus Cladina (Ahti 1957, Karaev 1961, Ahti and Hepburn 1967). This indicates other driving forces shaping the reindeer preference of lichens and may be connected to secondary compounds influencing nutrient balance.

It can be concluded from this study that although fiber was a major constituent in all lichens studied, the composition and solubility differed greatly among species and genera. These differences seem to be related to initial ruminal breakdown rate. Further studies are needed to investigate whether these differences in fiber composition and solubility may affect the nutritive value of the lichens for reindeer.

\section{Literature Cited}

Ahti, T. 1957. Newfoundland lichen stands and the wintering range of caribou. Nfld. Dept. Mines Resour. Wildl. Div. Mimes.

Ahti, T. And R.L. Hepburn. 1967. Preliminary studies on woodland caribou range, especially lichen stands in Ontario. Ont. Dep. Land. For. Res. Rept. (Wild1.) No. 74.

Andreyev, V.N. 1977. reindeer pastures in the subarctic territories of USSR, pp. 275-313. In: Krause, W. (ed), Handbook of Vegetation Science. Part Xiii. Application of vegetation science to grassland. Hague.

Blümmel, M. and E.R. Ørskov. 1993. Comparison of in vitro gas production and nylon bag degradability of roughages in predicting feed intake in cattle. Anim. Feed. Sci. Technol. 40:109-119.

Danell, K., P.M. Utsi, T.R. Palo, and O. Eriksson. 1994. Food plant selection by reindeer during winter in relation to plant quality. Ecography 17:153-158.

Elix, J.A., A.A. Whitton, and M.V. Sargent. 1984. Recent progress in the chemistry of lichen substances. Progr. Chem. Org. Nat. Products 45:103-234.

Englyst, H.N., M.E. Quigley, G.J. Hudson, and J.H. Cummings. 1992. Determination of dietary fiber as non-starch polysaccharides by gas-liquid chromatography. Analyst 117:1707-1714.

Eriksson, O., T. Palo, and L. Söderström. 1981. Reinbetning vintertid. Undersökningar rörande svensk tamrens näringsekologi under snöperioder. Växtekologiska Studier, 13, Uppsala, 92 pp.

Fincher, G.B. and B.A. Stone. 1986. Cell walls and their components in cereal grain technology, pp. 207-295. In: Pomeranz, Y. (ed), Adv. Cereal Sci. Technol. 8. AACC publications, St. Paul, Minn.

Gaare, E. and T. Skogland. 1980. Lichensreindeer interaction studied in a simple case model, pp. 47-56. In: Reimers, E., E. Gaare, and S. Skjenneberg (eds), Proc. $2^{\text {nd }}$ Int. Reindeer/Caribou Symp. Røros, Norway.

Garmo, T.H. 1986. Kjemisk innhald og in vitro fordøyelsesgrad av lav. Rangifer 6:8-13.

Henneberg, W. and F. Stohmann. 1859. Über das Erhaltungsfutter volljährigen Rindviehs. J. Landwirtsch. 3:485-551.

Holleman, D.F. and J.R. Luick. 1977. Lichen species preference by reindeer. Can. J. Zool. 55:1368-1369.
Iacomini, M., C.L. Schneider, and P.A.J. Gorin. 1985. Comparative studies on the polysaccharides of Cladina alpestris (reindeer moss), Cladina confusa, and Cladina amaurocraea. Carbohydr. Res. 142:237-251.

Ingolfsdottir, K., K. Jurcic, B. Fischer, and H. Wagner. 1994. Immunologically active polysaccharide from Cetraria islandica. Planta Med. 60:527- 531.

Jacobsen, E. 1981. Fordøyelighet av saltlav (Stereocaulon paschale) til rein. Rangifer 1:27-28.

Jacobsen, E. and S. Skjenneberg. 1976. Fordøyelighet av lav og tilskuddsfôr til rein. Forsk. Fors. Landbr. 27:287-305.

Karaev, G. I. 1961. (Engl. transl. 1968). Reindeer fodder resources. In P.S. Zhigunov (ed.) Reindeer Husbandry. Israel Program for Sci. Transl., U.S. Dept. Comm. Springfield, Va.:129-175

Klein, D.R. 1987. Vegetation recovery pattern following overgrazing by reindeer on St. Matthew Island. J. Range Manage. 40:336-338.

Krämer, P., U. Winicierz, J. Tschakert, W. Voelter, and H. Mayer. 1995. Rational approach to fractionation, isolation, and characterization of polysaccharides from the lichen Cetraria islandica. Drug Res. 45:726-731.

Lee, S.L., L. Prosky, and J.W. De Wries. 1992. Determination of total, soluble, and insoluble dietary fiber in foods-Enzymaticgravimetric method, MES-TRIS buffer: Collaborative study. J. Assoc. Off. Anal. Chem. 75:395-416.

McCleary, B.V. and R. Codd. 1991. Measurement of (1-3)(1-4)- $\beta$-D-glucan in barley and oats: a streamlined enzymic procedure. J. Sci. Food Agr. 55:303-312.

McCleary, B.V, T.S. Gibson, V. Solah, and D.C. Mugford. 1994. Total starch measurements in cereal products: interlaboratory evaluation of a apid enzymic test procedure. Cereal Chem. 71:501-505.

McEwan, E.H. and P.E. Whitehead. 1970. Seasonal changes in the energy and nitrogen intake in reindeer and caribou. Can. J. Zool. 48:905-913.

Menke, K.H. and H. Steingass. 1988. Estimation of the energetic feed value obtained from chemical analysis and in vitro gas production using rumen fluid. Anim. Res. Dev. 28:7-55.

Nordberg, H., V. Maijala and M. Nieminen. 1995. Forage preference of semi-domestic reindeer in northern Finland. $2^{\text {nd }}$ Int. Artic Ungulate Conference 13th-17th August 1995. University of Alasjka Fairbanks. Abstracts: 27.

Ørskov, E.R. and I. McDonald. 1979. The estimation of protein degradability in the rumen from incubation measurements weighed according to the rate of passage. J. Agr. Sci. 92:499-503.

Person, S.J., R.G. White, and J.R. Luick. 1979. Determination of nutritive value of reindeer-caribou range, pp. 224-239. In: Reimers, E., E. Gaare, and S. Skjenneberg (eds), Proc. $2^{\text {nd }}$ Int. Reindeer/Caribou Symp. Røros, Norway. 
Presthegge, K. 1954. Fors $\varnothing \mathrm{k}$ med lav til drøvtyggere og svin. Forsk. Fors. Landbr. 5:437-532.

Russell, D.E. and A.M. Martell. 1984. Winter range ecology of caribou (Rangifer taran dus), pp. 117-144. In: Olson, R., R. Hastings, and F. Geddes (eds), Northern Ecology and Resource Management. The University of Alberta Press, Edmonton, Alberta.

SAS. 1987. SAS/STAT user's guide, 6th ed. SAS Inst. Inc., Cary, USA. 1686 pp.

Solberg, Y.J. 1967. Studies on the chemistry of lichens. IV. The chemical composition of some Norwegian lichen species. Ann. Bot. Fenn. 4:29-34.
Solberg, Y.J. 1970. Studies on the chemistry of lichens. IX. Quantitative determination of monosaccharides and amino acids in hydrolysates of several Norwegian lichen species. Lichenologist 4:283-288.

Tveitnes, A. 1980. Lavgransking på Hardangervidda 1951-1979. Forskning og fors $\varnothing \mathrm{k}$ i landbruket, Suppl. 5: 287-364.

Van Soest, P.J. 1994. Nutritional ecology of the ruminant. $2^{\text {nd }}$ ed. Cornell Univ. Press, Ithaca and London.

Van Soest, P.J. and R.H. Wine. 1967. Use of detergents in the analysis of fibrous feeds. IV. Determination of plant cell-wall constituents. J. Assoc. Off. Anal. Chem. 50:50-55.
Virtala, M. 1992. Optimal harvesting of a plant-herbivore system: lichen and reindeer in northern Finland. Ecol. Mod. 60:233-255.

White, R.G. and J.R. Luick. 1984. Plasticity and constraints in the lactation strategy of reindeer and caribou. Symp. Zool. Soc. London 51:215

White, R.G., D.F. Holleman, M.E. Hubbert, and H. Staaland. 1987. Herbivores in cold climate, pp. 465-486. In: Hecker, J.B. and J.H. Ternouth (eds), The nutrition of herbivores. Second Int. Symp. on the nutrition of herbivores. Academic Press, Sydney. 